\title{
АКТУАЛЬНІ ПИТАННЯ ОРГАНІЗАЦІЇ ПІДГОТОВКИ КАДРІВ У СФЕРІ ОХОРОНИ ЗДОРОВ'Я
}

\author{
С. В. Григоровська, Ю. С. П’ятницький, О. П. Волосовець, Г. І. Гасюк, \\ К. І. Петрова
}

Міністерство охорони здоров'я України

\section{CURRENT ISSUES OF SPECIALISTS TRAINING ARRANGEMENT IN HEALTH CARE SYSTEM}

\author{
S. V. Hryhorovska, Yu. S. Pyatnytskyi, O. P. Volosovets, H. I. Hasiuk, K. I. Petrova \\ Ministry of Health of Ukraine
}

\begin{abstract}
У статті окреслено основні завдання, які стоять перед Міністерством охорони здоров’я та вищою медичною освітою щодо належного кадрового забезпечення системи охорони здоров'я та якості підготовки медичного персоналу. Вони можуть бути вирішені за умови впровадження сучасних стандартів підготовки медичних та фармацевтичних кадрів, розвитку віртуальної освіти та самоосвіти медиків, подальшого створення мережі університетських клінік та лікарень. Розподіл випускників здійснюється МОЗ України відповідно до потреб та пріоритетів галузі для першочергового забезпечення первинної та вторинної ланок сфери охорони здоров'я лікарськими кадрами. Ефективне використання наявних кадрових ресурсів в охороні здоров’я є спільним завданням регіонів та Міністерства охорони здоров’я України.
\end{abstract}

The article outlines the main tasks facing the Ministry of Health and higher medical education on proper staffing of public health care system and quality of training of medical personnel. They can be solved in case of implementing of modern standards of medical and pharmaceutical personnel training, development of virtual education and self-education of physicians, further creating a network of university clinics and hospitals. Ministry of Health of Ukraine is carried out the graduate employment according to the needs and priorities of the industry to ensure the priority of primary and secondary level of health care. The effective usage of available human resources in health care is a common problem of regional authorities and the Ministry of Health of Ukraine.

Вступ. Одним із найважливіших ресурсів успішної реалізації реформ є належне кадрове забезпечення та якість підготовки медичного персоналу. Цим питанням MO3 України приділяє постійну увагу, започаткувавши системну діяльність щодо розвитку дистанційного навчання та інтерактивних освітніх технологій [1].

Ті завдання, які стоять перед вищою медичною школою у ході розбудови галузі, можуть бути вирішені тільки за умови впровадження сучасних стандартів підготовки медичних та фармацевтичних кадрів, розвитку віртуальної освіти та самоосвіти медиків, подальшого створення мережі університетських клінік та лікарень.

Основна частина. Від кількісних показників оцінки роботи медичних університетів ми маємо зробити акценти на питаннях якості підготовки лікарів та медичних сестер у контексті запровадження нових засад організації післядипломної медич- ної освіти на основі комплексної моделі (інтернатура - лікарська резидентура - клінічна ординатура), яка на сьогодні розробляється Міністерством.

Необхідно й у подальшому стимулювати створення у системі МОЗ та НАМН України спільних освітньо-науково-практичних кластерів (інститут - університет - клініка), які б стали основою розробки новітніх лікувально-діагностичних технологій на базі доказової медицини та їх реального впровадження у практичну охорону здоров’я та на міжнародному рівні.

Новим Законом України “Про вищу освіту” передбачені принципово нові форми післядипломної медичної освіти та організації лікувального процесу у вищих медичних навчальних закладах: запроваджено лікарську резидентуру; передбачено можливість утворення вищими навчальними закладами університетських клінік та університетських лікарень [2]. Головна мета діяльності університетських

() С. В. Григоровська, Ю. С. П’ятницький, О. П. Волосовець та ін. 
клінік та лікарень - закладів охорони здоров’я, які $є$ структурними підрозділами вищих медичних навчальних закладів та закладів післядипломної освіти, - надання третинної (високоспеціалізованої), вторинної (спеціалізованої) медичної допомоги, забезпечення підготовки, перепідготовки та підвищення кваліфікації медичних працівників за стандартами вищої освіти, проведення науководослідної роботи, розробки, апробації та впровадження нових медичних технологій.

Згідно з частиною другою статті 13 Закону України “Про вищу освіту”, державні органи, до сфери управління яких належать вищі навчальні заклади, зокрема Міністерство охорони здоров’я України, здійснюють розподіл випускників вищих навчальних закладів, що належать до сфери їх управління, для подальшого проходження служби (для вищих військових навчальних закладів (вищих навчальних закладів із специфічними умовами навчання) та працевлаштування в заклади охорони здоров’я (для вищих медичних навчальних закладів) у межах державного замовлення [2].

Порядок працевлаштування випускників медичних навчальних закладів, підготовка яких здійснювалась за державним замовленням, регламентовано Постановою Кабінету Міністрів України від 22.08.1996 р. № 992 “Про Порядок працевлаштування випускників вищих навчальних закладів, підготовка яких здійснювалась за державним замовленням” (зі змінами) (далі-Постанова) та наказом MO3 України від 25.12.1997 р. № 367 “Про затвердження Порядку працевлаштування випускників державних вищих медичних (фармацевтичних) закладів освіти, підготовка яких здійснювалась за державним замовленням” (далі-Наказ), зареєстрованим у Міністерстві юстиції України 15.04.1998 р. за № 246/2686.

Державні замовники (структурні підрозділи 3 питань охорони здоров'я обласних, Київської міської державних адміністрацій) кожного року подають до МОЗ України, а в копії - до вищого навчального закладу, перелік конкретних місць працевлаштування та умов, які вони зобов’язуються створити випускникам наступного року зокрема, забезпечення житлом, розмір заробітної плати, інші соціальні гарантії, у тому числі передбачені регіональними програмами “місцевих стимулів” з урахуванням цільових направлень сільських районів та плану працевлаштування, затвердженого МО3 України.
Згідно з вимогами Постанови та Наказу випускники, які уклали угоду з вищим навчальним закладом після зарахування на навчання, зобов'язані відпрацювати за направленням не менше трьох років.

Таким чином, МОЗ України здійснює розподіл випускників відповідно до потреб та пріоритетів галузі для першочергового забезпечення первинної та вторинної ланок сфери охорони здоров’я лікарськими кадрами. Практично 100 \% випускників вищих медичних навчальних закладів, які навчались за державним замовленням, забезпечуються першим робочим місцем.

Разом $з$ тим зазначаємо, що натепер у закладах охорони здоров'я залишаються вакантними понад 20,7 тис. лікарських посад, зокрема понад 5,5 тис. осіб у закладах охорони здоров’я, які надають медичну допомогу переважно сільському населенню: в центральних районних лікарнях - 4015, районних лікарнях - 185, дільничних лікарнях - 37, сільських лікарських амбулаторіях - 1585.

У галузі працює майже 39 тис. лікарів пенсійного віку. Щороку зі сфери охорони здоров’я вибуває більше 7 тис. фахівців, що не компенсується щорічним обсягом державного розподілу випускників вищих медичних навчальних закладів, який становить близько 4 тис. осіб, з яких більше половини щороку направляються на роботу у заклади охорони здоров’я сільської місцевості. Щорічний обсяг державного замовлення на підготовку фахівців, який затверджується відповідною Постановою Кабінету Міністрів України (прийом), становить понад 5 тис. осіб та не повною мірою компенсує кадрові потреби галузі.

Ураховуючи зазначене, відповідно до чинних нормативно-правових актів Міністерство здійснює постійний контроль щодо організації працевлаштування молодих спеціалістів та у межах визначених повноважень і можливостей сприяє поліпшенню укомплектування закладів охорони здоров’я сільської місцевості та первинної ланки.

3 метою зменшення кадрового дефіциту, який має місце в галузі, Міністерство охорони здоров’я України вже зверталося до керівників обласних державних адміністрацій та голів обласних рад із пропозиціями щодо запровадження у регіонах програм “місцевих стимулів” для навчання студентів за лікарськими спеціальностями за кошти юридичних осіб - кошти місцевих бюджетів з укладенням відповідних угод для адресного працевлаштування 
цих випускників за направленням місцевих адміністрацій із зобов’ язанням відпрацювати на місцях не менше ніж три роки. У ряді областей та у м. Києві спільно з медичними університетами вже запроваджені цільові програми підготовки медичних кадрів за кошти місцевих бюджетів, проте коштів, які виділяються з місцевих бюджетів на відповідні цілі, є недостатньо для ліквідації кадрового дефіциту у регіонах.

Враховуючи викладене, МОЗ України зважає на необхідність підтримки на державному рівні розвитку програм “місцевих стимулів” у регіонах із наданням відповідних субвенцій з Державного бюджету України для цільової підготовки медичних кадрів в областях.

3 огляду на кадровий дефіцит, який має місце в галузі, Міністерство охорони здоров'я при плануванні державного замовлення на 2015-2017 рр. зверталося до Кабінету Міністрів України, Міністерства економічного розвитку і торгівлі України, Міністерства фінансів України з пропозицією збільшити обсяг державного замовлення на підготовку фахівців у 2015 р. до 6220 осіб, у 2016 р. - до 7720 осіб. Натомість, з огляду на граничні обсяги фінансування МОЗ України, визначені Державним бюджетом України на 2016 р., МОЗ України передбачить у 2016 р. обсяги державного замовлення на підготовку спеціалістів галузі знань “Охорона здоров’я” на рівні показників минулого року, що становить 5185 осіб.

Показники випуску фахівців та науковопедагогічних кадрів у 2016 р. формувалися за освітньо-кваліфікаційними рівнями та спеціальностями відповідно до Переліку спеціальностей, за якими здійснюється підготовка фахівців у вищих навчальних закладах за освітньо-кваліфікаційними рівнями спеціаліста і магістра, затвердженого Постановою Кабінету Міністрів України від 27.08.2010 р. № 787; Переліку напрямів, за якими здійснюється підготовка фахівців у вищих навчальних закладах за освітньо-кваліфікаційним рівнем бакалавра, затвердженого Постановою Кабінету Міністрів України від 13.12.2006 р. № 1719; Переліку спеціальностей, за якими здійснюється підготовка фахівців у вищих навчальних закладах за освітньо-кваліфікаційним рівнем молодшого спеціаліста, затвердженого Постановою Кабінету Міністрів України від 20.06.2007 р. № 839.

Показники прийому фахівців та науковопедагогічних кадрів у 2016 р. формувалися МО3
України з урахуванням Переліку галузей знань і спеціальностей, за якими здійснюється підготовка здобувачів вищої освіти, затвердженого Постановою Кабінету Міністрів України від 29.04.2015 р. № 266, з урахуванням вимог наказу Міністерства освіти і науки України від 06.11.2015 р. № 1151 “Про особливості запровадження переліку галузей знань і спеціальностей, за якими здійснюється підготовка здобувачів вищої освіти, затвердженого Постановою Кабінету Міністрів України від 29 квітня 2015 р. № 266”, зареєстрованого в Міністерстві юстиції України 25.11.2015р. за № 1460/27905.

Крім того, зауважимо, що пропозиції МОЗ України щодо державного замовлення для підготовки у галузевих вищих навчальних закладах магістрів за спеціальностями “Медична та психологічна реабілітація” і “Фізична реабілітація” (галузь знань “Охорона здоров’я”) були зумовлені необхідністю реалізації завдань, визначених у підпункті 5 пункту 3 Указу Президента України від 03.12.2015 р. № 678 “Про активізацію роботи щодо забезпечення прав людей з інвалідністю”, у 2016/2017 навчальному році.

Таким чином, спільними зусиллями центру та регіонів уперше за багато років збільшено обсяг підготовки лікарів загальної практики - сімейних лікарів для областей з найменшою укомплектованістю кадрами. Для Міністерства охорони здоров’я України і в подальшому буде залишатися пріоритетним питання кадрового забезпечення первинної ланки й системи екстреної та невідкладної медичної допомоги. На виконання рішень колегій MO3 України, як і раніше, буде приділятися особлива увага якісному кадровому забезпеченню фтизіатричної і лабораторної служби та мережі перинатальних центрів. Звичайно, що кадрове забезпечення повинно належним чином економічно мотивуватись. Проте це не знімає відповідальності 3 керівництва регіонів щодо подальшого розвитку започаткованих регіональних програм “місцевих стимулів” для соціального захисту медичних працівників, особливо “молодих спеціалістів”. Таким чином, ефективне використання кадрових ресурсів в охороні здоров'я - спільне завдання регіонів та Міністерства охорони здоров’я України.

Висновки: 1. Завдання, які стоять перед вищою медичною освітою, можуть бути вирішені за умови впровадження сучасних стандартів підготовки медичних та фармацевтичних кадрів, розвитку віртуальної освіти та самоосвіти медиків, подаль- 
шого створення мережі університетських клінік та лікарень.

2. МОЗ України здійснює розподіл випускників відповідно до потреб та пріоритетів галузі для першочергового забезпечення первинної та вто-

\section{Список літератури}

1. Про вищу освіту : Закон України від 01.07.2014 р. № 1556-VII.

2. Сучасні завдання вищої медичної освіти та кадрового забезпечення реформування галузі / Т. М. Старча, ринної ланок сфери охорони здоров'я лікарськими кадрами.

3. Ефективне використання кадрових ресурсів в охороні здоров'я є спільним завданням регіонів та Міністерства охорони здоров’я України.

О. П. Волосовець, І. В. Клоченко [та ін.] // Медична освіта. - 2015. - № 2. - С. 9-13. 